УДК 9.902.2

https://doi.org/10.24852/2587-6112.2020.5.89.92

\title{
ЛАНДШАФТНЫЕ ФАКТОРЫ В ОРГАНИЗАЦИИ ЖИЛОГО ПРОСТРАНСТВА НАСЕЛЕНИЯ МАРИЙСКОГО ПОВОЛЖЬЯ ВО ІІ-І ТЫС. ДО Н.Э.
}

\section{(C) 2020 г. Е.Е. Воробьева}

Статья направлена на изучение одного из наиболее актуальных вопросов в организации поселений II нач. І тыс. до н.э. - природного ландшафта. Рельеф, наличие и близость водных ресурсов, климатические условия, видовой состав фауны, флора - все это оказывало существенное воздействие на все стороны жизни общества, прежде всего, на его хозяйственную деятельность, что приводило к выработке адаптивных механизмов, освоению новых территорий, организации поселенческого пространства. Иными словами, ландшафтные факторы были первостепенными в организации поселений. Статья представляет возможности такого анализа на примере поселений II-I тыс. до н.э., расположенных на территории Марийского Поволжья. Итогом исследования явились выводы автора о своеобразии организации поселений рассматриваемого периода на территории Марийского Поволжья. Установлено влияние ландшафтных факторов по таким основным критериям, как: топография поселений, отношение пола (основания) к древней поверхности, форма жилища, тип конструкции, строительный материал.

Ключевые слова: археология, ландшафт, поселения, домостроительство, жилище, Марийское Поволжье.

\section{LANDSCAPE FACTORS IN THE ORGANIZATION OF SETTLEMENTS OF THE MARI VOLGA REGION IN THE II — I MILLENNIA BC}

\author{
E.E. Vorobeva
}

The article aims to the study of one of the most current issues in the organization of settlements of the $2^{\text {nd }}$ - early $1^{\text {st }}$ Millennia $\mathrm{BC}$ - the natural landscape. The relief, availability and proximity of water resources, climatic conditions, and the species composition of the fauna and flora had a significant impact on all aspects of the society, and especially its economic activities; led to the development of adaptive mechanisms, development of new territories, organization of settlement space. In other words, landscape factors were paramount in the organization of settlements. The article describes the possibilities of such analysis on the example of settlements of the $2^{\text {nd }}-1^{\text {st }}$ Millennia BC located on the territory of the Mari Volga region. As a result, conclusions were made by the author about the peculiarity of the organization of settlements of the period in question in the territory of the Mari Volga region. The influence of landscape factors was established in relation to such basic criteria as the topography of settlements, ratio of the floor (base) to the ancient surface, shape of the dwellings, type of structures, and building materials.

Keywords: archaeology, landscape, settlements, housebuilding, dwelling, Mari Volga region.

В современной археологической науке прочно утвердилось мнение о взаимодействии в древности человека и окружающей его природы, в процессе которого «...человек стремится приспособить окружающей его мир к своим потребностям, но так, чтобы это могло обеспечить успешное осуществление трудовой деятельности» (Викторова, 1984, с. 13). Домостроительство, в основе которого лежала выработанная поколениями целесообразность формирующих его элементов жилого или хозяйственного сооружений, было консервативно и тесно скоррелировано исторической средой, одним из компонентов которой выступает природный ландшафт.
Природным ландшафтом называют территорию, однородную по происхождению и включающую в себя совокупность таких компонентов, как геологическое строение, климат, рельеф, почвенно-растительный покров, гидрологическую сеть и т. д. (Исаченко, 1991, с. 5-7).

Целью данного исследования является анализ влияния ландшафтных факторов на организацию поселений на территории Марийского Поволжья во II-I тыс. до н. э.

Марийское Поволжье подразумевает регион, который включает в себя правобережье p. Волги от правого берега р. Суры на западе до правого берега р. Сундырь на востоке; левый берег p. Волги ограничен с запада $\mathrm{p}$. 
Дорогучей, на востоке бассейнами притоков р. Волги: реками Илеть, Большая и Малая Кокшаги, Парат.

Сегодня на данной территории известно 75 поселений II - нач. I тыс. до н. э., позволяющих использовать их в качестве предмета исследования (Никитин, 2002, с. 45).

Согласно устоявшейся точке зрения, период, охватывающий II-I тыс. до н. э. на территории Марийского Поволжья, совпал со средней и завершающей фазами суббореального периода в лесной полосе. Первая из них (SBII, 4100-3200 л. н.) характеризовалась как фаза пониженной увлажненности с потеплением и спадом уровня воды гидрологической сети, расцветом широколиственных лесов. Завершающая фаза отличалась повышенной увлажненностью с похолоданием (Шнирельман, 1989, с. 159; Шнитников, 1958, с. 38).

Спад уровня воды, потепление повлекли за собой изменение русла р. Волги и её притоков, распространение широколиственных лесов. Данные факторы прежде всего отразились на изменении топографии поселений рассматриваемого периода.

Так, если поселенческие памятники Марийского Поволжья в первой четверти II тыс. до н. э. занимают мыс, высокий край надлуговых террас рек, озер, то во второй четверти II тыс. до н. э. наблюдается перенос поселений на узкие и низкие песчаные косы (в пойме реки) в удалении от основного русла, а в некоторых случаях (Выжумская II стоянка, Удельно-Шумецкой комплекс) - на заливаемые дюны пойм. Это свидетельствует, по мнению А.Х. Халикова (Халиков, 1969, c. 163), о возможном потеплении климата ближе к середине II тыс. до н. э. Однако, судя по наличию слабо выраженного культурного слоя, можно предположить, что некоторые такие поселения носили сезонный характер и несли в себе функцию временного убежища в момент внезапного нападения (Никитин, 1991, c. 13).

В настоящее время на археологическую карту Марийского Поволжья нанесено свыше 70 памятников второй половины II - нач. I тыс. до н. э. (Никитин В.В., Соловьев Б.С., 2002, с. 45). Они характеризуются устойчивой топографией, занимая левобережье р. Волги и её притоков: Большой и Малой Кокшаги, Илети и Парата. При этом преобладают поселения, расположенные на естественно укрепленных мысах надпойменных террас высотой 2-6 м крупных рек, меньше - на дюнных всхолмле- ниях, вытянутых вдоль рек, старичных озер, проток; редко - на низких берегах коренных террас и озер.

Климатические условия повлияли и на отношение пола (основания) к уровню древней поверхности. Следует отметить, что все исследованные сооружения данного периода на территории Марийского Поволжья имеют углублённость. При этом углубленность оснований сооружений II - нач. I тыс. до н. э. на территории Марийского Поволжья варьирует в пределах 5-120 см. Подавляющая часть (более $75 \%$ ) изученных сооружений имеет основания, устроенные ниже уровня древней поверхности от 40 до 120 см. Остальные менее $40 \mathrm{~cm}$.

Особенности строительной техники, обусловленные природно-климатическими условиями исследуемого региона (постройка должна быть надежным убежищем в достаточно суровых зимних условиях Марийского края), а также необходимость выравнивания площадки под строительство жилого или хозяйственного сооружений, расчистки основания от накопившегося мусора при строительстве требовали углубления основания. Но следует заметить, что это было необходимо даже при строительстве жилищ и наземного типа, что увеличивало теплоизоляцию помещения. Не исключено, что глубина котлована зависела от сезона использования сооружения (холодное или теплое время года), а также от его функционального назначения (жилище, подсобное помещение и т. п.).

Таким образом, исходя из данных наблюдений, мы можем с уверенностью говорить о том, что сооружения на территории Марийского Поволжья во II - нач. I тыс. до Н. э. фиксируются в двух вариантах: наземные (с незначительным углублением котлована - до 39 см) и углубленные (основание углублено по отношению к древней поверхности от 40 и более см).

Устойчивые и стабильные свойства среды, в частности тип экологической ниши (долины, поймы рек) и такие климатические условия, как количество осадков, сила инсоляции, оказали свое влияние на разнообразие построек по форме основания. На материалах поселенческих памятников рассматриваемого периода территории Марийского Поволжья в настоящее время известны два варианта данного критерия - сооружения квадратной и прямоугольной форм. Наиболее распространенная и устойчивая - прямоугольная форма 
(более 70\% из всех полно изученных сооружений). Квадратная форма встречена у 18\% изученных сооружений. Форма основания у $9 \%$ неизвестна по причине отсутствия фиксации одного из показателей параметров основания (либо длины, либо ширины). При этом анализ исследованных сооружений показывает, что на территории Марийского Поволжья во II - нач. I тыс. до н. э. преобладают углубленные сооружения прямоугольной формы.

По периметру котлованов как прямоугольных, так и квадратных, как углублённых, так и наземных на уровне пола четко прослеживаются насыщенные гумусные и углистые полосы шириной 15-25 см, а также примыкавшие к ним многочисленные ямы диаметром 20-25 см, расположенные с равными промежутками друг от друга. Вероятно, у наземных жилищ они являются остатками основания стен, а у углублённых - впущенного в грунт деревянного каркаса из горизонтально уложенных друг на друга бревен, крепившихся вертикально врытыми столбами. Это свидетельствует о преимущественном преобладании в рассматриваемый период каркасно-столбовой конструкции. Однако на некоторых сооружениях поселений (жилище № 1 Ахмыловского поселения, Мольбищенское поселение) следы столбовых ям либо отсутствовали, либо были выявлены в центре котлована, что позволяет предполагать наличие сруба.

О широком использовании дерева в строительстве сооружений в данный период свидетельствуют и палинологические данные.
Споро-пыльцевые образцы из построек двух поселений, относящихся к II тыс. до н. э., показали абсолютное преобладание пыльцы сосны (свыше 85\%), березы (11\%), липы (4\%), дуба (Никитин В.В., Соловьев Б.С., 2002, с. 18). Обработка и осмысление данного археологического материала позволяют сделать следующее заключение. Влияние природного ландшафта на домостроительство населения Марийского Поволжья во II - нач. I тыс. до н. э. проявилось в совокупности природных характеристик и традиций располагать поселения либо на естественно укрепленных мысах надпойменных террас, либо на дюнных всхолмлениях, вытянутых вдоль рек, старичных озер, проток; либо на низких берегах коренных террас и озер; строить сооружения каркасно-столбовой или срубной конструкций из доступного и наиболее распространенного материала (дерево, земля), придавать ту или иную в плане форму (прямоугольная, квадратная), соотносить пол (основание) с древней поверхностью (наземное, углубленное сооружение).

Поселения являются на сегодняшний день важными источниками для изучения хозяйственной деятельности, социально-экономических отношений населения во II - нач. I тыс. до н. э. В связи с этим для восстановления социально-экономического уклада населения необходимо более детальное изучение организации жизненного пространства, где анализ влияния ландшафтных факторов является неотъемлемой частью.

\section{ЛИТЕРАТУРА}

Викторова В.Д. Обоснование программы археологических исследований поселений // Древние поселения Урала и Западной Сибири / Отв. ред. В.Е. Стоянов. Свердловск: Изд-во УрГУ, 1984. С. 7-14. $366 \mathrm{c}$.

Исаченко А.Г. Ландшафтоведение и физико-географическое районирование. М.: Высш. шкл., 1991.

Никитин В.В. Медно-каменный век Марийского края (середина III - начала II тысячелетия до н.э.). Йошкар-Ола: МарНИИЯЛИ, 1991. 152 с.

Никитин В.В., Соловьев Б.С. Поселения и постройки Марийского Поволжья (эпоха камня и бронзы) / Труды МарАЭ. Т. VII. Йошкар-Ола: МарНИИЯЛИ, 2002. 162 с.

Халиков А.Х. Древняя история Среднего Поволжья. М.: Наука, 1969. 394 с.

Шнитников A.B. Изменчивость общей увлажненности материков северного полушария // Записки географического общества СССР. Т.16. М-Л., 1957. С.38.

Шнирельман B.A. Возникновение производящего хозяйства: проблема первичных и вторичных очагов. М.: Наука, 1989. 444 с.

\section{Информация об авторе:}

Воробьева Елена Евгеньевна, кандидат исторических наук, доцент кафедры истории Татарстана, археологии и этнологии Института международных отношений Казанского федерального университета (г. Казань, Россия); veer47@mail.ru 


\section{REFERENCES}

Viktorova, V. D., 1984. In Stoyanov, V. E. (ed.). Drevnie poseleniya Urala i Zapadnoy Sibiri (Ancient Settlements of the Urals and Western Siberia). Sverdlovsk: Ural State University, 7-14 (in Russian).

Isachenko, A. G. 1991. Landshaftovedenie i fiziko-geograficheskoe rajonirovanie (Landscape Studies and Physico-Geographical Zoning). Moscow "Vysshaia shkola” Publ. (in Russian).

Nikitin, V. V. 1991. Medno-kamennyi vek Mariiskogo kraia (seredina III - nachalo II tysiacheletiia do n. e.) (The Copper and Stone Age of Mari Region (Middle of 3rd - Early 2nd Millennia BC)). Yoshkar-Ola: Mari Scientific and Research Language, Literature, History and Ethnography Institute (in Russian).

Nikitin, V. V., Solov'ev, B. S. 2002. Poseleniia i postroiki Mariiskogo Povolzh 'ia (epokha kamnia i bronzy) (Settlements and Dwellings of the Mari Volga Region: Stone and Bronze Ages). Series: Trudy Mariiskoi arkheologicheskoi ekspeditsii (Proceedings of Mari Archaeological Expedition) VII. Yoshkar-Ola: Mari Scientific and Research Language, Literature, and History Institute (in Russian).

Khalikov, A. Kh. 1969. Drevniaia istoriia Srednego Povolzh'ia (Ancient History of the Middle Volga Region). Moscow: "Nauka" Publ. (in Russian).

Shnitnikov, A. V. 1957. In Zapiski geograficheskogo obshchestva SSSR ((Proceedings of the Geographic Society of USSR) 16. Moscow, Leningrad (in Russian).

Shnirelman, V. A. 1989. Vozniknovenie proizvodjashhego hozjajstva: problema pervichnyh $i$ vtorichnyh ochagov (Emergence of Producing Economies: the Issues of Primary and Secondary Centers). Moscow: "Nauka" Publ. (in Russian).

\section{About the Author:}

Vorobeva Elena E. Candidate of Historical Sciences. Docent. Kazan (Volga Region) Federal University. Kremlyovskaya St., 18, Kazan, 420000, the Republic of Tatarstan, Russian Federation. veer47@mail.ru 